\title{
Construction of Listeria monocytogenes Mutants with In-Frame Deletions in Putative ATP-Binding Cassette (ABC) Transporters and Analysis of Their Growth under Stress Conditions
}

\author{
Yanhong Liu' ${ }^{1 *}$, Marina Ceruso ${ }^{2}$, Nereus W. Gunther IV', Tiziana Pepe $^{2}$, Maria Luisa Cortesi ${ }^{2}$ and Pina Fratamico ${ }^{1}$
}

${ }^{1}$ Molecular Characterization of Food borne Pathogens Research Unit, Eastern Regional Research Center, Agricultural Research Service, U.S. Department of Agriculture, 600 East Mermaid Lane, Wyndmoor, PA 19038, USA

2Dipartimento di Scienze Zootecniche e Ispezione degli Alimenti, Sezione Ispezione, Facoltà di Medicina Veterinaria, Università degli Studi di Napoli Federico II, Via Delpino 1, Naples 80137, Italy

\begin{abstract}
Listeria monocytogenes is a food-borne pathogen that is difficult to eliminate since it can survive under different stress conditions such as low $\mathrm{pH}$ and high salt. Understanding its survival under stress conditions is important in controlling this pathogen in food. ABC transporters have been shown to be induced in $L$. monocytogenes subjected to high pressure and nisin treatments; therefore, we hypothesized that genes encoding the $A B C$ transporters may be involved in general stress responses. To study the function of these genes, deletion mutants of $A B C$ transporter genes (LMOf2365 1875, LMOf2365 1877) were created in L. monocytogenes F2365, and these deletion mutants were tested under different stress conditions. Compared to the wild type, $\Delta$ LMOf2365_1875 and $\Delta$ LMOf2365_1877 showed slower growth under nisin $(250 \mu \mathrm{g} / \mathrm{ml})$ and acid $(\mathrm{pH} 5)$ treatments. Under salt treatment $(5 \% \mathrm{NaCl}$ in minimal medium), $\Delta$ LMOf2365_1877 showed slower growth whereas $\Delta$ LMOf2365_1875 had growth similar to the wild type. Moreover, $\Delta$ LMOf2365 1875 had an increased capacity to form biofilms compared to the wild type. Our results indicate that these deletion mutants may be more sensitive to multiple stress conditions compared to the wild type, suggesting that LMOf2365 1875 and LMOf2365 1877 may contribute to the general stress response in $L$. monocytogenes. An understanding of the growth of these mutants under multiple stress conditions and their ability to form biofilms may help in the development of intervention strategies to control $L$. monocytogenes in food and in the environment.
\end{abstract}

Keywords: ABC transporter; Listeria monocytogenes; Stress response Introduction

Listeria monocytogenes is a food-borne pathogen responsible for human listeriosis, an invasive infection with high mortality rates. Listeriosis is responsible for an estimated 2500 serious illnesses and 500 deaths each year in the United States, accounting for $28 \%$ of annual deaths attributable to known food-borne pathogens, second only to deaths due to Salmonella infections [1]. The disease affects primarily pregnant women, newborns, the elderly and immune-compromised individuals, due to uncontrolled intracellular replication within host cells [2]. Transmission of L. monocytogenes is generally through eating contaminated food, in particular, dairy products made from unpasteurized milk and ready-to-eat meat and fish products [3]. In addition, $L$. monocytogenes has been found in a variety of raw foods such as uncooked meats and vegetables, as well as in processed foods that become contaminated after processing, such as soft cheeses and cold cuts at the deli counter [3,4]. Potential sources of $L$. monocytogenes contamination in foods include the incoming product, food handlers, consumers, and environmental sources, such as utensils and equipment, which may harbor pathogenic microorganisms or serve as vehicles of contamination if cleaning and sanitation procedures are poor [5]. L. monocytogenes is widely distributed in the environment, forms biofilms, and is relatively resistant to acid and high salt concentrations [6]. Unlike most food-borne pathogens, L. monocytogenes multiplies readily in refrigerated foods [7].

In response to changes in the natural environment, bacteria undergo a complex program of differential gene expression. A number of transcriptional regulators important for stress response gene expression have been identified in L. monocytogenes [8-10], and the pathogen has developed efficient strategies for survival under stress conditions, such as starvation, wide variations in temperature, $\mathrm{pH}$, and osmolarity [11] The regulation of gene expression in response to environmental stress conditions is essential for bacterial survival [12]. Proteins induced by heat shock and other stress conditions include proteases and ATP-dependent chaperones. Energy dependent proteolysis plays an important role in the turnover of both abnormal proteins and naturally short-lived, specific regulatory proteins $[13,14]$. In the Gram-positive model organism, B. subtilis, expression of heat shock genes involves at least four different regulatory mechanisms $[15,16]$. Class I heat shock genes encode classical chaperones, such as GroES, GroEL, and DnaK, and they are controlled by the HrcA repressor. Class II genes encode general stress proteins whose transcription is dependent on the alternative $\sigma^{\mathrm{B}}$ [16]. Class III heat shock genes encode ClpP and two Hsp100 Clp ATPases, ClpC and ClpE, and these form part of the CtsR stress response regulon. These genes are negatively controlled by CtsR, the product of the first gene of the ClpC operon $[15,17,18]$.

*Corresponding author: Yanhong Liu, Molecular Characterization of Food borne Pathogens Research Unit, Eastern Regional Research Center, Agricultura Research Service, U.S. Department of Agriculture, 600 East Mermaid Lane Wyndmoor, PA 19038 USA, Tel: +215-233-6587; Fax: +215-233-6581; E-mail: Yanhong.Liu@ars.usda.gov

Received November 09, 2012; Accepted November 22, 2012; Published November 24, 2012

Citation: Liu Y, Ceruso M, Gunther IV NW, Pepe T, Cortesi ML, et al. (2012) Construction of Listeria monocytogenes Mutants with In-Frame Deletions in Putative ATP-Binding Cassette (ABC) Transporters and Analysis of Their Growth under Stress Conditions. J Microb Biochem Technol 4: 141-146. doi:10.4172/19485948.1000085

Copyright: @ 2012 Liu Y, et al. This is an open-access article distributed under the terms of the Creative Commons Attribution License, which permits unrestricted use, distribution, and reproduction in any medium, provided the original author and source are credited 
Citation: Liu Y, Ceruso M, Gunther IV NW, Pepe T, Cortesi ML, et al. (2012) Construction of Listeria monocytogenes Mutants with In-Frame Deletions in Putative ATP-Binding Cassette (ABC) Transporters and Analysis of Their Growth under Stress Conditions. J Microb Biochem Technol 4 : 141-146. doi:10.4172/1948-5948.1000085

Class IV includes stress response genes such as $\mathrm{ftsH}$, lonA, clpX, and htpG whose expression is independent of $\operatorname{HrcA}, \sigma^{\mathrm{B}}$ or CtsR and whose regulatory mechanisms remain to be identified $[15,16]$.

In 2001, the genome sequence of the prototype L. monocytogenes serotype 1/2a strain EGDe [19] was published, which heralded the launch of the post-genomic era for L. monocytogenes research. Three years later, the complete sequence of the epidemic serotype $4 \mathrm{~b}$ clone F2365 was deciphered [20]. More recently, a bank of 16 animal, food, and environmental $L$. monocytogenes isolates was sequenced by the BROAD Institute MIT. The resulting sequences should provide an invaluable source of information for identification of genetic determinants involved in stress responses and the environmental biology of the organism.

A typical $\mathrm{ABC}$ transporter consists of several subunits with the following structural domains: a nucleotide-binding domain, a transmembrane domain, or a solute-binding domain [21]. All ABC transporters are either exporters or importers. There are more than 30 copies of different $\mathrm{ABC}$ transporters present in the genome of $L$. monocytogenes. Some $\mathrm{ABC}$ transporters have been shown to be involved in biofilm formation, and in responses to acid and salt stress [22-25]. $\mathrm{ABC}$ transporters were also involved in resistance to antimicrobials such as nisin that acts on the cell envelope [26,27].

LMOf2365_1875 (ABC transporter, manganese-binding protein), LMOf2365_1876 (manganese ABC transporter; permease protein) and LMOf2365_1877 (manganese ABC transporter; ATP-binding protein) were highly induced in milk [28]; however, this operon was inhibited in ready-to-eat meats [29]. These gene complexes are involved in manganese transport. Manganese is involved in a number of cellular functions such as virulence and oxidative stress [30]. For example, deletion of the putative $\mathrm{Mn}$ (II) ABC transporter (MntA) in B. anthracis resulted in increased sensitivity to oxidative stress [31]. Since this ABC transporter operon was induced with a number of treatments such as high pressure and nisin [32], we hypothesized that this operon may be involved in general stress responses. Therefore, the in-frame deletion mutants, LMOf236_1875 and LMOf2365_1877, were constructed and mutant growth was tested under different stress treatments such as exposure to nisin, acid, and salt.

\section{Materials and Methods \\ Bacteria and growth conditions}

L. monocytogenes strain F2365 isolated from Mexican-style soft cheese that was implicated in an outbreak of listeriosis in California in 1985 [33] was used in this study since its genome is fully sequenced and annotated [20]. Glycerol stock cultures of L. monocytogenes F2365 and isogenic mutants of this parent strain (Table 1) stored at $-80^{\circ} \mathrm{C}$ were streaked onto Brain Heart Infusion (BHI) (Sigma-Aldrich St. Louis, $\mathrm{MO}$ ) agar plates and grown at $37^{\circ} \mathrm{C}$ prior to each experiment.

\section{Construction of in-frame deletion mutants LMOf2365_1875 and LMOf2365_1877 in L. monocytogenes F2365}

Gene deletion fragments were constructed by splice overlap extension (SOE) PCR [34] to generate two 400-bp fragments: one upstream including the $\mathrm{ATG}$ codon (AB product) and one downstream beginning from the stop codon ( $\mathrm{CD}$ product). The sequences and positions of PCR primers are listed in table 1 and figure 1 . The 5 ' end of the SOEB primers had about $20 \mathrm{bp}$ complementary to the SOEC primers. The initial PCR products were diluted 1:20 in PCR-grade water, and $1 \mu \mathrm{l}$ of each product was used as a template in a second round of PCR with the SOEA and SOED primers to generate an 800-bp product (PCR product $A D$ ). The $2^{\text {nd }}$ round PCR products were purified using the QIAquick PCR Purification Kit (QIAGEN, Valencia, CA) and quantified using a Nanodrop ND100 UV-Vis spectrophotometer (Thermo Scientific, Inc., Wilmington, DE). The $2^{\text {nd }}$ round PCR products and pKSV7 vector (a gift from S. Kathariou, North Carolina State University) were digested with $\mathrm{KpnI}$ and $\mathrm{XbaI}$ restriction enzymes, cloned into the pKSV7 vector and transformed into $E$. coli competent cells (C4040-03, Invitrogen, Carlsbad, CA) according to the manufacturer's instructions. Transformants were selected on Luria-Bertani (LB) agar containing $100 \mu \mathrm{g} / \mathrm{ml}$ ampicillin and X-Gal (5-bromo-4-chloro-3-indolyl- $\beta$-Dgalactopyranoside) (Calibochem, Merck, Darmstadt, Germany). White colonies were screened by colony PCR, using primers $\mathrm{A}$ and $\mathrm{D}$ and then sequenced. The plasmids containing PCR product AD were electroporated into L. monocytogenes F2365 as described [35]. The transformants were serially passaged at $40^{\circ} \mathrm{C}$ in $\mathrm{BHI}$ with $10 \mu \mathrm{g} / \mathrm{ml}$ chloramphenicol to select for the cells in

\begin{tabular}{|c|c|c|}
\hline Strains/plasmids/primers & Description & $\begin{array}{l}\text { Source or } \\
\text { reference }\end{array}$ \\
\hline $\begin{array}{l}\text { E. coli strains } \\
\text { TOP10 } \\
\text { DH5a }\end{array}$ & $\begin{array}{l}\text { competent cells } \\
\text { competent cells }\end{array}$ & $\begin{array}{l}\text { Invitrogen } \\
\text { Invitrogen }\end{array}$ \\
\hline $\begin{array}{l}\text { Plasmids } \\
\text { pKSV7 }\end{array}$ & Temperature-sensitive integration vector; $\mathrm{Cm}^{r}$ & $\begin{array}{l}\text { gift from S. } \\
\text { Kathariou }\end{array}$ \\
\hline $\begin{array}{l}\text { L. monocytogenes strains } \\
\text { F2365 } \\
\Delta \text { LMOf2365_1875 } \\
\Delta \text { LMOf2365_1877 }\end{array}$ & $\begin{array}{l}\text { Wild-type serotype } 4 \mathrm{~b} \text { strain, genome sequenced } \\
\text { LMOf2365_1875 deletion } \\
\text { LMOf2365_1877 deletion }\end{array}$ & $\begin{array}{l}\text { Nelson et al. [20] } \\
\text { This study } \\
\text { This study }\end{array}$ \\
\hline $\begin{array}{l}\text { Primers } \\
\text { F2365_1875SOEA } \\
\text { F2365_1875SOEB } \\
\text { F2365_1875SOEC } \\
\text { F2365_1875SOED } \\
\text { F2365_1877SOEA } \\
\text { F2365_1877SOEB }\end{array}$ & $\begin{array}{l}\text { 5'GGGGTACCGCTTTCCCGCTTAGTGTTGC3' } \\
\text { 5'GGGAGGTTATCGAATGAAATAAAAAAAGACGCAGAGATTAAC3' } \\
\text { 5'TTTCATTCGATAACCTCCC3'' } \\
\text { 5'GCTCTAGAGCGAAAAGTAGTACAGATTTG3' } \\
\text { 5'GGGGTACCACTCCGCACCGCAAGCAC3' } \\
\text { 5'GTGGGAAAAGGGTGGTTTAGATGTAATAGATGTTGTTTTTAGAAGG3' }\end{array}$ & $\begin{array}{l}\text { This study } \\
\text { This study } \\
\text { This study } \\
\text { This study } \\
\text { This study } \\
\text { This study }\end{array}$ \\
\hline $\begin{array}{l}\text { F2365_1877SOEC } \\
\text { F2365_1877SOED }\end{array}$ & $\begin{array}{l}\text { 5'CATCTAAACCACCCTTTTCCCAC3' } \\
\text { 5'GCTCTAGAGAATTAGCTAAAACGCTTG3' }\end{array}$ & $\begin{array}{l}\text { This study } \\
\text { This study }\end{array}$ \\
\hline
\end{tabular}

Restriction sites (Kpnl and Xbal) are highlighted in bold. Regions overlapping complementary to SOEC primers are underlined

Table 1: Strains, plasmids and primers used in this study. 
Citation: Liu Y, Ceruso M, Gunther IV NW, Pepe T, Cortesi ML, et al. (2012) Construction of Listeria monocytogenes Mutants with In-Frame Deletions in Putative ATP-Binding Cassette (ABC) Transporters and Analysis of Their Growth under Stress Conditions. J Microb Biochem Technol 4 141-146. doi:10.4172/1948-5948.1000085

which the plasmid had integrated into the chromosome by homologous recombination. Colonies obtained during subsequent passages at $30^{\circ} \mathrm{C}$ in BHI without chloramphenicol were screened for chloramphenicol sensitivity (colonies that did not grow on the BHI/ chloramphenicol plates) that indicates a second homologous recombination event with loss of the plasmids. Chloramphenicol sensitive colonies were screened by colony PCR using SOEA and SOED primers to identify isolates with the mutant alleles. The size of the fragment in the deletion mutant was about $800 \mathrm{bp}$ while the sizes in the wild type were $800 \mathrm{bp}$ plus the size of the deleted genes.

Growth assays for L. monocytogenes F2365 wild type and $\Delta L M O f 2365 \_1875, \Delta L M O f 2365 \_1877$ under different stress conditions

L. monocytogenes F2365 (wild type), and the $\Delta$ LMOf2365_1875 and $\Delta$ LMOf2365_1877 mutants were used for growth assays. To make a log-phase culture, one L. monocytogenes colony was inoculated into $5 \mathrm{~mL} \mathrm{BHI}$ and grown at $37^{\circ} \mathrm{C}$ with agitation at $200 \mathrm{rpm}$ overnight. A $50-\mu \mathrm{l}$ aliquot of overnight culture was added into $5 \mathrm{~mL} \mathrm{BHI}$ and grown at $37^{\circ} \mathrm{C}$ with agitation at $180 \mathrm{rpm}$ for $3 \mathrm{~h}$ until the $\mathrm{OD}_{600}$ was 0.4. Growth assays were performed in a 96-well plate format using log-phase bacteria. The lid of the microtiter plate was pre-treated with $0.05 \%$ Triton X-100 in $20 \%$ ethanol to eliminate liquid condensation. After 15-30 s, the treatment solution was poured off and the cover was leaned against a vertical surface and allowed to air-dry [36]. For the nisin inhibition assay, nisin (containing 2.5\% pure nisin, balance sodium chloride and denatured milk solids, activity of 1 X $10^{6} \mathrm{IU} / \mathrm{g}$, according to the manufacturer) from Lactococcus lactis was purchased from Sigma-Aldrich (N5764). Nisin at a concentration of $250 \mu \mathrm{g} / \mathrm{ml}$ in $\mathrm{BHI}$ was used for growth studies, and $0.02 \mathrm{~N} \mathrm{HCl}$ was used as a negative control. For the salt tolerance assays, log-phase cells were harvested by centrifugation at $5000 \mathrm{rpm}$ at $4^{\circ} \mathrm{C}$ for $10 \mathrm{~min}$ and resuspended in 5 $\mathrm{mL}$ of Minimal Medium (MM) [37] with $0.5 \%$ glucose. MM with 5\% $\mathrm{NaCl}$ and $0.5 \%$ glucose was used to for the growth studies. $\mathrm{BHI}$ at $\mathrm{pH}$ 5 was used for the acid tolerance assays, and $\mathrm{BHI}$ at $\mathrm{pH} 7$ was used as a control. The plate was placed into a Safire II spectrophotometer (Tecan) at $37^{\circ} \mathrm{C}$, with $\mathrm{OD}$ readings at $\lambda 600 \mathrm{~nm}$ taken every hour for $18 \mathrm{~h}$.

\section{Biofilm assays}

Five milliliters of Mueller-Hinton broth overnight cultures of L. monocytogenes F2365 (wild type), $\Delta$ LMOf2365_1875, and $\Delta$ LMOf2365_1877 were initiated from plate grown isolates. The overnight cultures were incubated at $32^{\circ} \mathrm{C}$ with agitation $(200 \mathrm{rpm})$. The next day, the overnight cultures were diluted 1:100 into fresh Mueller-Hinton broth. Flat bottom cell culture 96-well microtiter plates (Greiner Bio-one, Monroe, NC) were washed with 100\% ethanol and allowed to air dry in a biological hood until all residual ethanol had evaporated. For each strain, $100 \mu \mathrm{l}$ of the freshly diluted culture were placed in 8 different wells. Additionally, $100 \mu \mathrm{l}$ sterile Mueller-Hinton broths were also placed in 8 additional wells as the negative control. The plates were incubated statically at $32^{\circ} \mathrm{C}$ for $48 \mathrm{~h}$. The wells were then observed to determine if visible biofilms were present in the $L$. monocytogenes inoculated wells. The medium was then removed from the microtiter plate wells, and the individual wells were washed 5 times with $150 \mu \mathrm{l}$ of sterile distilled water. The plates were then allowed to air dry for $45 \mathrm{~min}$, and then $150 \mu \mathrm{l}$ of $1 \%$ crystal violet solution were added to each of the wells. After $45 \mathrm{~min}$, the stain was removed, and the wells were washed 5 times with $150 \mu \mathrm{l}$ sterile distilled water. The wells were then destained of the residual biofilm-bound crystal violet with
$200 \mu \mathrm{l}$ of $95 \%$ ethanol. One hundred microliters of the destain mixture were then transferred to a new microtiter plate, and the OD $590 \mathrm{~nm}$ was measured for each well. The resulting data for three separate trials were subjected to an analysis of variance. The individual trials were considered as a block when performing the mean separations using the least significant difference technique at a $p<0.05$ level [38].

\section{Results and Discussion}

\section{Genetic organization of the $\mathrm{ABC}$ operon and in silico analysis of LMOf2365_1875, 1876, and 1877}

The whole genome of L. monocytogenes F2365 has been sequenced [20]. DNA sequence analysis indicates that the composition of the ABC transporter operon is comprised of three genes: LMOf2365_1875 (encoding for $\mathrm{ABC}$ transporter, manganese-binding protein), LMOf2365_1876 (encoding for manganese ABC transporter, permease protein) and LMOf2365_1877 (encoding for manganese ABC transporter, ATP binding protein). This operon is transcribed from the opposite direction ( $3^{\prime}$ to $5^{\prime}$ ) in the genome. Blast searches from NCBI databases indicated that the protein encoded by LMOf2365_1876 is predicted to contain 8 transmembrane domains. A conserved domain search (http://www.ncbi.nlm.nih.gov/cdd) indicated that LMOf2365_1875 encodes the domain for the metal binding protein, PsaA. LMOf2365_1876 encodes for transmembrane subunit (TM) of periplasmic binding protein (PBP)-dependent ATP-Binding Cassette (ABC) transporters, and LMOf2365_1877 contains the domain for the ATP-binding cassette domain of the metal-type transporters.

Wewere unable to obtain a deletion mutant for LMOf2365_1876. The in-frame deletion mutants for LMOf2365_1875 and LMOf2365_1877 were constructed using SOE primers (Table 1). The mutants were generated by an in-frame deletion of the entire gene with only the first or second amino acid and the stop codon remaining. $\Delta$ LMOf2365_1875 had amino acids 3 to 310 removed, and $\Delta$ LMOf2365_1877 had amino acids 2 to 236 removed. These in-frame deletions were verified by PCR (Figure 1) and confirmed by sequencing.

\section{Effect of different stress conditions (nisin, acid, and salt) on mutant growth}

Growth phenotypes of the LMOf2365 parental strain and its isogenic $\Delta$ LMOf2365_1875, and $\Delta$ LMOf2365_1877 mutants were tested under types of stress potentially experienced by this pathogen in food-associated environments: nisin, salt, and acid. As shown in figure $2 \mathrm{~A}$, with the treatment with $250 \mu \mathrm{g} / \mathrm{ml}$ nisin, the $\mathrm{OD}_{600}$ values of $\Delta$ LMOf2365_1875 and $\Delta$ LMOf2365_1877 were significantly lower than that of the wild type between 0 and $16 \mathrm{~h}$ at $37^{\circ} \mathrm{C}$. The fact that mutants grew slower compared to the wild type at the concentration of $250 \mu \mathrm{g} / \mathrm{ml}$ nisin indicates that mutants were more sensitive to nisin. At $\mathrm{pH} 5, \Delta \mathrm{LMOf} 2365 \_1875$ and $\Delta$ LMOf2365_1877 began to grow more slowly after 6-8 $\mathrm{h}$, and the difference in growth between the mutants and the wild type was maximum at $12 \mathrm{~h}$ (Figure 2B). Under salt (5\% NaCl in minimal medium) treatment, $\Delta$ LMOf2365_1875 grew similarly to the wild type whereas $\Delta$ LMOf2365_1877 grew slower than the wild type. The difference in growth was maximum at $10 \mathrm{~h}$ (Figure $2 \mathrm{C})$. We also tested growth of the mutants in the presence of verapamil (0-30 mM) (a known ABC transporter inhibitor) and in food (apple juice and milk); however, the mutants grew similarly as compared to the wild type under these conditions (data not shown). 
Citation: Liu Y, Ceruso M, Gunther IV NW, Pepe T, Cortesi ML, et al. (2012) Construction of Listeria monocytogenes Mutants with In-Frame Deletions in Putative ATP-Binding Cassette (ABC) Transporters and Analysis of Their Growth under Stress Conditions. J Microb Biochem Technol 4 : 141-146. doi:10.4172/1948-5948.1000085

\section{$\Delta$ LMOf2365_1877 mutant had an increased capacity for biofilm formation}

$\mathrm{ABC}$ transporters have been shown to be associated with biofilm formation in L. monocytogenes [22,23]. Biofilm assays were performed to determine if biofilm formation of $\triangle$ LMOf2365_1875 and $\Delta$ LMOf2365_1877 was different from that of the wild type. As shown in figure 3, $\Delta$ LMOf2365_1875 formed more biofilm than the wild type whereas bioflm formation by $\Delta$ LMOf2365_1877 was similar to that of the wild type (Figure 3).

\section{Discussion}

In this paper, in-frame deletions of $\mathrm{ABC}$ transporters (LMOf2365_1875 and LMOf2365_1877) were constructed, and the growth of these deletion mutants was tested under food-related stress conditions. We were unable to obtain a deletion mutant of LMOf2365_1876 through multiple attempts because this gene may be essential to cell survival. The effect of nisin was investigated because it has antimicrobial activity and can be used as a food preservative [39]. The effect of salt was studied because salt is often used as a general preservative and food additive to enhance the flavor and shelf life of food [40]. pH 5 was selected for the acid tolerance assay because human gastric $\mathrm{pH}$ is between 3.0 and 5.0 during food digestion, and L. monocytogenes is generally consumed with contaminated food [41]. Furthermore, the $\mathrm{pH}$ of cheese that is often implicated in listeriosis

\section{A}

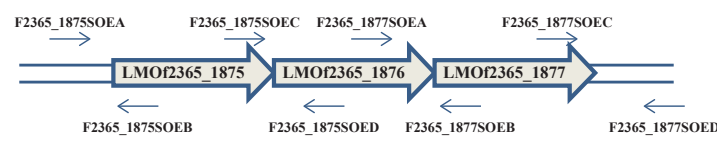

B

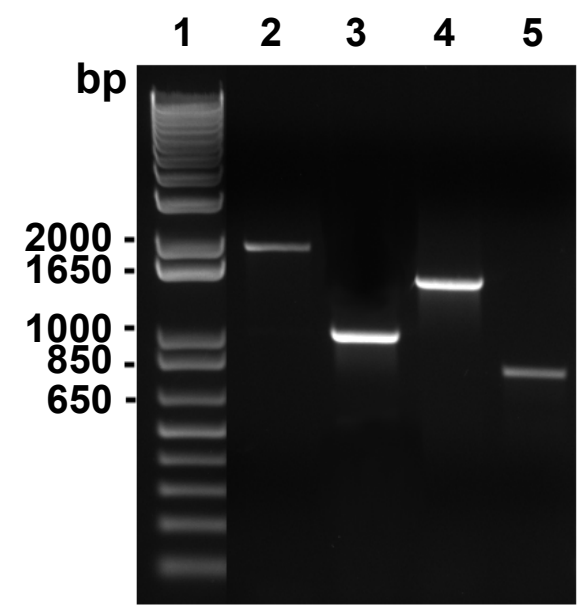

Figure 1: Schematic diagram of the ABC transporter (LMOf23651875-1877) operon in L. monocytogenes F2365 genome (A) and generation of chromosomal deletion mutants (B). A. LMOf2365 1877 encoded a manganese ABC transporter; ATP-binding protein, LMOf2365 1876 encodes for manganese ABC transporter; permease protein. LMOf2365_1875 encodes for ABC transporter; manganese-binding protein. Arrows indicate the position of primers used for mutant generation (not drawn to scale). B. PCR products of the wild-type genes (LMOf2365_1875, LMOf2365_1877) and the genes from the respective deletion mutants ( $\triangle$ LMOf2365_1875 and $\Delta$ LMOf2365_1877) amplified using specific primers (SOEA and SOED) flanking each gene. Lane 1, $1 \mathrm{~kb}$ Plus DNA ladder, Lane 2, LMOf2365 1875 gene and flanking region of the wild type. Lane 3, flanking region of $\Delta$ LMOf2365_1875. Lane 4, LMOf2365_1877 gene and flanking region of the wild type. Lane 5, flanking region of $\Delta$ LMOf2365_1877. The predicted sizes are as follows: LMOf2365 1875, 1978bp; $\Delta$ LMOf2365_1875, 1054bp; LMOf2365_1877, 1565bp; $\Delta$ LMOf2365_1877, 718bp.

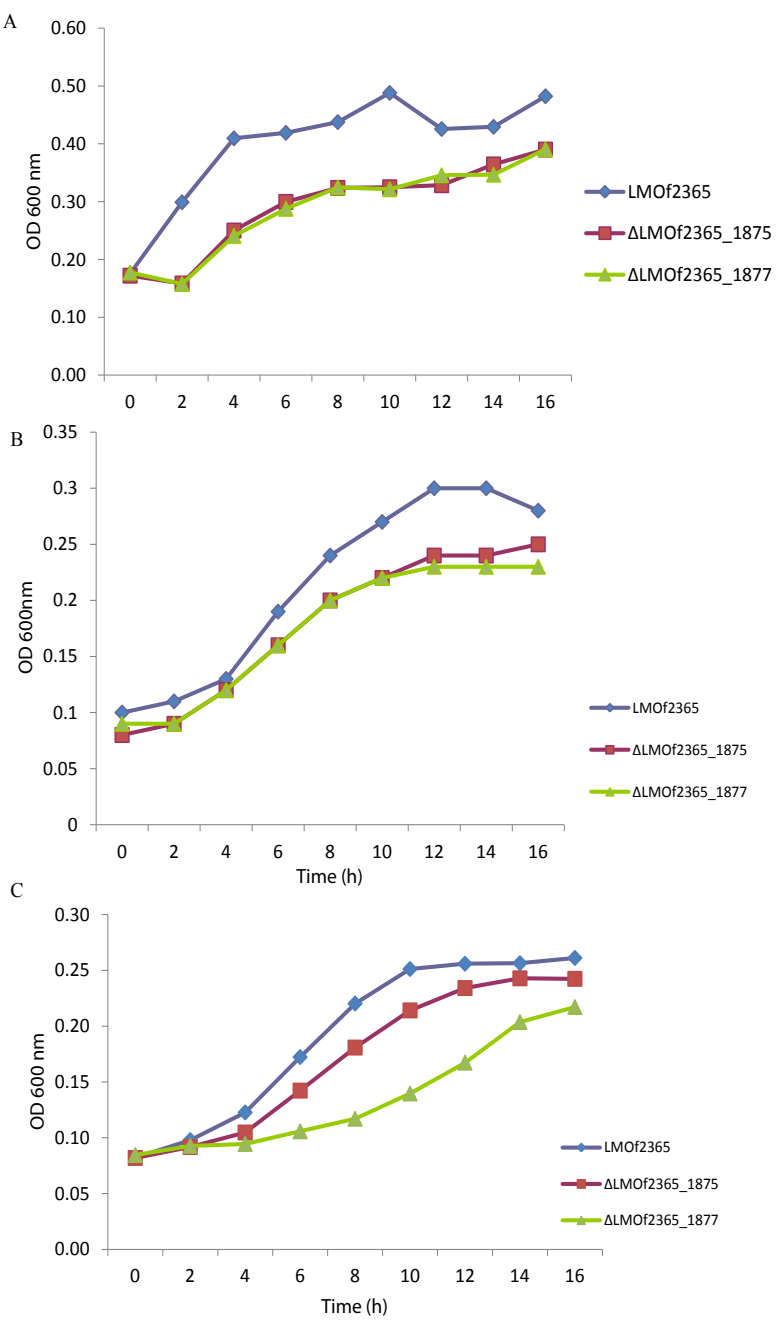

Figure 2: Growth curves of L. monocytogenes F2365, $\Delta$ LMOf2365_1875 and $\triangle$ LMOf2365_1877 at $37^{\circ} \mathrm{C}$ in (A) nisin $(250 \mu \mathrm{g} / \mathrm{ml}$ in BHI), (B) acid (BH to $\mathrm{pH} 5$ with $\mathrm{HCl})$, and $(\mathrm{C})$ salt $(5 \% \mathrm{NaCl}$ in minimal medium). Cell growth was measured spectrophotometrically by monitoring the $\mathrm{OD}_{\text {a }}$ at 2-h intervals for 16 $\mathrm{h}$ at $37^{\circ} \mathrm{C}$. Data shown here are averages of three independent experiments.

outbreaks is usually pH 5 [42], and L. monocytogenes mounts an acid tolerance response after exposure to this $\mathrm{pH}$ [43]. Biofilm formation was also tested since it is a major reason for the persistence of $L$. monocytogenes on food contact surfaces and imposes important challenges to the production of safe food by the food industry [44].

LMOf2365_1875, 1876, 1877 showed over a ten-fold induction using a DNA microarray assay and over 70 -fold induction by realtime quantitative PCR assays [28]. The current work extends our previous studies through the construction of the knock-out mutants to determine a phenotype. We were puzzled by the fact that although LMOf2365_1875 and LMOf2365_1877 were highly induced in milk, the knock-out mutants of LMOf2365_1875 and LMOf2365_1877 grew similarly in milk (data not shown). Our results indicate that the induction of genes by microarray and/or real-time PCR assays does not necessarily result in a strong phenotype at the growth level.

Although the mutants grew more slowly than the wild type under stress conditions such as nisin, salt, and acid treatments in laboratory medium, they may behave differently in food matrices. Studying 


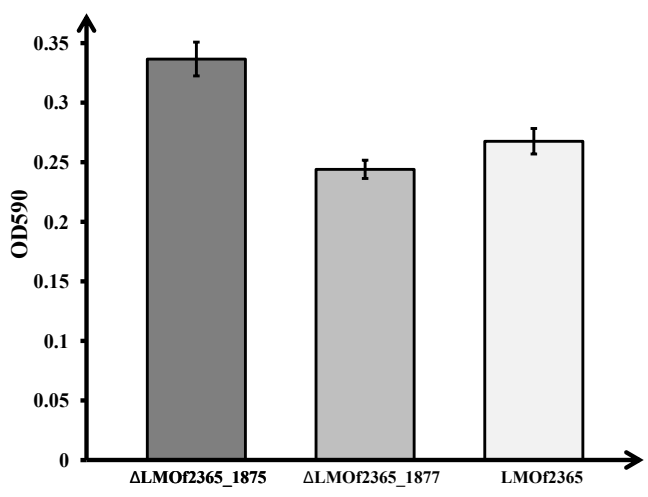

Figure 3: Growth curves of L. monocytogenes F2365, $\Delta$ LMOf2365_1875 and $\Delta$ LMOf2365_1877 at $37^{\circ} \mathrm{C}$ in $(\mathrm{A})$ nisin $(250 \mu \mathrm{g} / \mathrm{ml}$ in BHI), (B) acid $(\mathrm{BH}$ l acidified to $\mathrm{pH} 5$ with $\mathrm{HCl}$ ), and $(\mathrm{C})$ salt $(5 \% \mathrm{NaCl}$ in minimal medium). Cell growth was measured spectrophotometrically by monitoring the $\mathrm{OD}_{600}$ at 2-h intervals for 16 $\mathrm{h}$ at $37^{\circ} \mathrm{C}$. Data shown here are averages of three independent experiments.

bacterial growth in food matrices is much more complex than in culture media. For example, LMOf2365_1877 was induced in milk [28] but inhibited in meat [29]. Food matrices may provide different factors to regulate gene expression, and further studies in our laboratory will continue to explore growth of the L. monocytogenes mutants on food matrices.

Although the deletion mutants showed some sensitivity to nisin, acid, and salt, the differences compared to the wild type were not large. The growth of mutants was not affected by verapamil (data not shown), which is a well-known ABC transporter inhibitor [45]. The effect of another antimicrobial compound (bacitracin) on mutant growth was also investigated (data not shown) and resulted in no growth difference. Oxidative stress assays using hydrogen peroxide also showed no differences in growth between the mutants and wild type (data not shown). Growth with different carbon sources including mannose, fructose, raffinose, sorbitol, sucrose, xylose and glucose did not affect mutant growth (data not shown). Finally, phenotypic array (Biolog, Inc., Hayward, CA) screening for these two deletion mutants and the wild type was performed and only minor differences were observed (data not shown). The lack of an identifiable phenotype may possibly be due to the fact that activity of the genes can be replaced by other similar genes in the cell since there are other $\mathrm{ABC}$ transporters present in the genome. Our notion is supported by the fact that deletion of an $\mathrm{ABC}$ transporter in Lactobacillus plantarum also resulted in no phenotype change [46]. This may suggest that L. monocytogenes is highly adaptive in response to inactivation of these genes or, alternatively, that other $\mathrm{ABC}$ transporters that have not yet been identified are also involved in sensitivity to acid and salt in L. monocytogenes.

In L. monocytogenes, one ABC transporter (lm.G_1771) encoding a putative $\mathrm{ABC}$ transporter permease has been reported to be involved in negative regulation of biofilm formation since deletion of this gene resulted in increased capacity to form biofilms [22]. The $\Delta 1771$ mutant was further characterized by genomic and proteomic analysis. DNA microarrays and two-dimensional gel electrophoresis revealed 49 and 11 differentially expressed genes and proteins in $\Delta 1771$, respectively [23]. In our study, $\Delta$ LMOf2365_1875 also showed increased capacity for biofilm formation compared to the wild type, although LMOf2365_1875 showed very little homology to lm.G_1771. In Streptococcus mutans, deletion of an $\mathrm{ABC}$ transporter resulted in impaired capacity to form biofilms [25]. $\triangle$ LMOf2365_1875 and $\Delta$ LMOf2365_1877 were sensitive to nisin, indicating that these genes might be responsible for nisin resistance. Consistent with our data, deletion of another ABC transporter (anrB) in L. monocytogenes [27] also showed sensitivity to nisin. However, the $A B C$ operon examined in the current study has a different chromosomal location and showed little homology in sequences to the $\mathrm{ABC}$ transporters described by Collins et al. [27]. ABC transporters are located on cell membranes that are usually targets for the action of nisin. Our findings also suggest that putative $\mathrm{ABC}$ transporters have the potential to be used as targets for the development of new antimicrobials against $L$. monocytogenes.

\section{Acknowledgments}

We thank Amy Ream for performing the real-time PCR assays. We are also grateful to Dr. James Smith (USDA, Agricultural Research Service, Eastern Regional Research Center, Wyndmoor, PA) for critical reading of the manuscript.

\section{References}

1. Mead PS, Slutsker L, Dietz V, McCaig LF, Bresee JS, et al. (1999) Food-related illness and death in the United States. Emerg Infect Dis 5: 607-625.

2. Roberts AJ, Wiedmann M (2003) Pathogen, host and environmental factors contributing to the pathogenesis of listeriosis. Cell Mol Life Sci 60: 904-918.

3. European Food Safety Authority (2009) The community summary report on trends and sources of zoonoses and zoonotic agents in the European Union in 2009. Euro Food Safety Authority J. 2011 9: 2090.

4. Cordano AM, Rocourt J (2001) Occurrence of Listeria monocytogenes in food in Chile. Int J Food Microbiol 70: 175-178.

5. Lianou A, Sofos JN (2007) A review of the incidence and transmission of Listeria monocytogenes in ready-to-eat products in retail and food service environments. J Food Prot 70: 2172-2198.

6. McClure PJ, Kelly TM, Roberts TA (1991) The effects of temperature, pH, sodium chloride and sodium nitrite on the growth of Listeria monocytogenes. Int J Food Microbiol 14: 77-91.

7. Koseki S, Isobe S (2005) Growth of Listeria monocytogenes on iceberg lettuce and solid media. Int J Food Microbiol 101: 217-225.

8. Hanawa T, Kai M, Kamiya S, Yamamoto T (2000) Cloning, sequencing and transcriptional analysis of the dnaK heat shock operon of Listeria monocytogenes. Cell Stress Chaperones 5: 21-29.

9. Leimeister-Wächter M, Haffner C, Domann E, Goebel W, Chakraborty T (1990) Identification of a gene that positively regulates expression of listeriolysin, the major virulence factor of Listeria monocytogenes. Proc Natl Acad Sci USA 87: 8336-8340.

10. Nair S, Derré I, Msadek T, Gaillot O, Berche P (2000) CtsR controls class III heat shock gene expression in the human pathogen Listeria monocytogenes. Mol Microbiol 35: 800-811.

11. Gray ML, Killinger AH (1966) Listeria monocytogenes and listeric infections Bacteriol Rev 30; 309-382.

12. Akbar S, Kang CM, Gaidenko TA, Price CW (1997) Modulator protein RsbR regulates environmental signalling in the general stress pathway of Bacillus subtilis. Mol Microbiol 24: 567-578.

13. Gottesman S, Wickner S, Maurizi MR (1997) Protein quality control: triage by chaperones and proteases. Genes Dev 11: 815-823.

14. Squires C, Squires CL (1992) The Clp proteins: proteolysis regulators or molecular chaperones? J Bacteriol 174: 1081-1085.

15. Derré I, Rapoport G, Msadek T (1999) CtsR, a novel regulator of stress and heat shock response, controls clp and molecular chaperone gene expression in gram-positive bacteria. Mol Microbiol 31: 117-131.

16. Hecker M, Schumann W, Völker U (1996) Heat-shock and general stress response in Bacillus subtilis. Mol Microbiol 19: 417-428.

17. Krüger E, Hecker M (1998) The first gene of the Bacillus subtilis clpC operon, 
Citation: Liu Y, Ceruso M, Gunther IV NW, Pepe T, Cortesi ML, et al. (2012) Construction of Listeria monocytogenes Mutants with In-Frame Deletions in Putative ATP-Binding Cassette (ABC) Transporters and Analysis of Their Growth under Stress Conditions. J Microb Biochem Technol 4 : 141-146. doi:10.4172/1948-5948.1000085

ctsR, encodes a negative regulator of its own operon and other class III heat shock genes. J Bacteriol 180: 6681-6688.

18. Derré I, Rapoport G, Devine K, Rose M, Msadek T (1999) ClpE, a novel type of HSP100 ATPase, is part of the CtsR heat shock regulon of Bacillus subtilis. Mol Microbiol 32: 581-593.

19. Glaser P, Frangeul L, Buchrieser C, Rusniok C, Amend A, et al. (2001) Comparative genomics of Listeria species. Science 294: 849-852.

20. Nelson KE, Fouts DE, Mongodin EF, Ravel J, DeBoy RT, et al. (2004) Whole genome comparisons of serotype $4 \mathrm{~b}$ and $1 / 2 \mathrm{a}$ strains of the food-borne pathogen Listeria monocytogenes reveal new insights into the core genome components of this species. Nucleic Acids Res 32: 2386-2395.

21. Tam R, Saier MH Jr (1993) Structural, functional, and evolutionary relationships among extracellular solute-binding receptors of bacteria. Microbiol Rev 57: 320-346

22. Zhu X, Long F, Chen Y, Knøchel S, She Q, Shi X (2008) A putative ABC transporter is involved in negative regulation of biofilm formation by Listeria monocytogenes. Appl Environ Microbiol 74: 7675-7683.

23. Zhu X, Liu W, Lametsch R, Aarestrup F, Shi C, et al. (2011) Phenotypic, proteomic, and genomic characterization of a putative ABC-transporter permease involved in Listeria monocytogenes biofilm formation. Foodborne Pathog Dis 8: 495-501.

24. Vanderlinde EM, Harrison JJ, Muszyński A, Carlson RW, Turner RJ, et al (2010) Identification of a novel ABC transporter required for desiccation tolerance, and biofilm formation in Rhizobium leguminosarum bv. viciae 3841 . FEMS Microbiol Ecol 71: 327-340.

25. Seaton K, Ahn SJ, Sagstetter AM, Burne RA (2011) A transcriptional regulator and $A B C$ transporters link stress tolerance, (p)ppGpp, and genetic competence in Streptococcus mutans. J Bacteriol 193: 862-874.

26. Majchrzykiewicz JA, Kuipers OP, Bijlsma JJ (2010) Generic and specific adaptive responses of Streptococcus pneumoniae to challenge with three distinct antimicrobial peptides, bacitracin, LL-37, and nisin. Antimicrob Agents Chemother 54: 440-451.

27. Collins B, Curtis N, Cotter PD, Hill C, Ross RP (2010) The ABC transporter AnrAB contributes to the innate resistance of Listeria monocytogenes to nisin, bacitracin, and various beta-lactam antibiotics. Antimicrob Agents Chemother 54: 4416-4423

28. Liu Y, Ream A (2008) Gene expression profiling of Listeria monocytogenes strain F2365 during growth in ultrahigh-temperature-processed skim milk. Appl Environ Microbiol 74; 6859-6866.

29. Bae D, Crowley MR, Wang C (2011) Transcriptome analysis of Listeria monocytogenes grown on a ready-to-eat meat matrix. J Food Prot $74 ; 1104-$ 1111.

30. Papp-Wallace KM, Maguire ME (2006) Manganese transport and the role of manganese in virulence. Annu Rev Microbiol 60: 187-209.
31. Gat O, Mendelson I, Chitlaru T, Ariel N, Altboum Z, et al. (2005) The solutebinding component of a putative $\mathrm{Mn}(\mathrm{II}) \mathrm{ABC}$ transporter (MntA) is a nove Bacillus anthracis virulence determinant. Mol Microbiol 58: 533-551.

32. Liu Y, Ream A, Joerger RD, Liu J, Wang Y (2011) Gene expression profiling of a pressure-tolerant Listeria monocytogenes Scott A ctsR deletion mutant. J Ind Microbiol Biotechnol 38: 1523-1533.

33. Linnan MJ, Mascola L, Lou XD, Goulet V, May S, et al. (1988) Epidemic listeriosis associated with Mexican-style cheese. N Engl J Med 319: 823-828.

34. Horton RM, Cai ZL, Ho SN, Pease LR (1990) Gene splicing by overlap extension tailor-made genes using the polymerase chain reaction. Biotechniques 8: 528535

35. Park SF, Stewart GS (1990) High-efficiency transformation of Listeria monocytogenes by electroporation of penicillin-treated cells. Gene 94: 129-132.

36. Brewster JD (2003) A simple micro-growth assay for enumerating bacteria. $J$ Microbiol Methods 53: 77-86.

37. Premaratne RJ, Lin WJ, Johnson EA (1991) Development of an improved chemically defined minimal medium for Listeria monocytogenes. Appl Environ Microbiol 57: 3046-3048.

38. Miller RG (1981) Simultaneous Statistical Inference, Second Edition. New York, NY: Springer-Verlag 67-70.

39. Gálvez A, Abriouel H, López RL, Ben Omar N (2007) Bacteriocin-based strategies for food biopreservation. Int J Food Microbiol 120: 51-70.

40. Ruusunen M, Puolanne E (2005) Reducing sodium intake from meat products Meat Sci 70: 531-541.

41. Cotter PD, Hill C (2003) Surviving the acid test: responses of gram-positive bacteria to low pH. Microbiol Mol Biol Rev 67: 429-453.

42. Faleiro ML, Andrew PW, Power D (2003) Stress response of Listeria monocytogenes isolated from cheese and other foods. Int J Food Microbio 84: 207-216.

43. Gahan CG, O'Driscoll B, Hill C (1996) Acid adaptation of Listeria monocytogenes can enhance survival in acidic foods and during milk fermentation. Appl Environ Microbiol 62: 3128-3132.

44. Carpentier B, Cerf O (2011) Review--Persistence of Listeria monocytogenes in food industry equipment and premises. Int J Food Microbiol 145: 1-8.

45. Seral C, Carryn S, Tulkens PM, Van Bambeke F (2003) Influence of P-glycoprotein and MRP efflux pump inhibitors on the intracellular activity of azithromycin and ciprofloxacin in macrophages infected by Listeria monocytogenes or Staphylococcus aureus. J Antimicrob Chemother 51: 11671173.

46. Groot MN, Klaassens E, de Vos WM, Delcour J, Hols P, et al. (2005) Genome-based in silico detection of putative manganese transport systems in Lactobacillus plantarum and their genetic analysis. Microbiology 151: 12291238. 